\title{
INCREASING PEDAGOGIC COMPETENCY AND PROFESSIONAL COMPETENCY THROUGH EDUCATION AND TRAINING DEVELOPMENT OF SUSTAINABLE PROFESSION OF DEVELOPMENT (Case Study of Kindergarten Teachers in Bandung)
}

\author{
Rita Nurunnisa
}

IKIP Siliwangi

ritanurunnisa@rocketmail.com

\begin{abstract}
Teacher competence is the teacher's capital in carrying out the main task and its function in educating the students. There are 4 competencies that must be possessed by teachers, namely, pedagogic competence, professional competence, personality competence and social competence. Teachers should have awareness in themselves to continue to learn and develop themselves continuously in an effort to improve services to learners. One of the teacher's efforts in self-development is through education and training. For that, the authors examine the "How education and training Sustainable Development of Keprofesian in improving the pedagogic and professional competence of kindergarten teachers in Bandung?" Where pedagogic competence and professional competence are both mutually integrated and can not be separated. This study aims to describe the process of planning, implementation, assessment and results and the impact of education and training on teacher performance through descriptive and qualitative approaches. The results of this study indicate through education and training program Sustainable Development of Keprofesian in Bandung value Competency Teacher Test average increased significantly and in accordance with the expected minimum achievement criteria. In addition, teachers also feel an increase in knowledge, variations of learning fun to apply to learners and implement sustainable self-development plans.
\end{abstract}

Keywords: Pedagogic competence, professional competence, teacher, education, and training

\section{A. INTRODUCTION}

The teacher is the vanguard of a nation's reversal, with great responsibilities under which the progress and success of a nation are determined. Various professions in this life, starting from the top of the president, ministers, businessmen, doctors, architects, soldiers, police and other professions is the work of a teacher. Teachers who instill the values of attitudes, knowledge, and skills so it is expected to grow generations that can compete in this era of globalization.

To carry out its function, then there is a competence that must be owned by a teacher. Competence is a set of knowledge, attitudes, skills and basic values possessed by a person manifested in the mindset and pattern of action in everyday life. There are 4 
competencies that must be possessed by a teacher, namely pedagogic competence, professional competence, personality competence and social competence.

Given the importance of each teacher must have the pedagogical and professional competence to support its function in the noble task of educating the students, through education and training of the learner-teacher can give a positive influence on the pedagogic and professional competence of the teacher, this research takes the title "Increase Pedagogic Competence and Competence Professional Teachers through Education and Training Programs of Sustainable Cultural Development "

\section{FORMULATION OF THE PROBLEM}

Based on the above description, then the problem formulation in this research is "How is education and training of Sustainable Development of Keprofesian in improving pedagogic competence and professional kindergarten teacher in Bandung?"

\section{B. THEORY STUDY}

\section{Understanding Educators}

Based on Law Number 20 the Year 2003, Article 1 paragraph 6 states that educators are qualified personnel as teachers, lecturers, counselors, guardians, widyaiswara, tutors, instructors, facilitators and other designations in accordance with their specificity, and participate in the provision of education. Furthermore, in general, terms described educators are qualified personnel as teachers, lecturers, counselors, among learn, widya iswara, tutors, instructors, facilitators, and other designations in accordance with the specificity, and participate in the implementation of education. (Law No. 20 the Year 2003 Article 1).

Associated with the term educator in Early Childhood Education, then there are different names but have the same meaning. These terms include the term teacher for those who teach in kindergarten and elementary, the term among learning for those who teach in Learning Activity Center (SKB). Later on, the term facilitator tutor, mother, ustadz-uztadzah who organizes Play Group education, TPA (daycare), TPQ (Koran Education Place), cadres in BKB and Posyandu. But all of them have the same understanding that as an early childhood educator.

\section{Understanding Early Childhood Education Competencies}

Competence according to Indonesian Dictionary is competitiveness; circumstances have sufficient skill and knowledge in any case; authority or power to decide or decide something (2014: 462).

In English there are at least three terms that imply what is meant by the words of the competence (Saud, 2011: 44)

1) "competence" (n) is being competent, ability (to do the work) "

2) "competent (adj.) Refers to (persons) having ability, power, authority, skill, knowledge, etc. (to do what is needed)

3) "competency is a rational performance which satisfactorily meets the objectives for a desired condition" 
The first definition shows that the competence basically indicates that the competence basically shows to the skills or ability to do the job. While the second definition shows further that the competence is basically a trait (characteristic) of people (competent) is that have the ability, ability, authority, skills, knowledge, etc. to do required. Then the third definition, furthermore, is that the competence shows the rational (performance) action that can achieve its objectives satisfactorily based on expected conditions (prerequisites).

In contrast to educational services at other levels of education, services provided by an early childhood teacher (TK) are also eligible to be expressed as expert services, as kindergarten teachers must also be able to take non-routine decisions in the execution of their daily tasks. As illustrated in the Professional Teacher Education Academy Manuscript (Ditjen Dikti, 2006), the applied services of educational experts are always based on complete academic mastery so that an expert describes it as an applied science-based art. Meanwhile, on the other hand the figure of educator can be assumed as an expert who always reflects on what has been and will be done in the implementation of its services in the context of long-term consequences of all decisions and actions (informed responsiveness) both for children as individuals and for the community where the child concerned it is alive, all of which is of course also based on appropriate academic considerations (Ditjen Dikti, 2006). This means that in the implementation of the service, a kindergarten teacher should also care about the side of kemengapaan (normative referral), in addition to the kebagaimanaan (procedural reference) and side when (contextual referral) in taking each decision and action.

\section{Relationship of Pedagogic Competence and Professional Competence}

Pedagogical competence and professional competence are two aspects of integrated competence so that its formation cannot be separated. In relation to that, then the whole figure of professional competence of early childhood teachers includes the ability, to know the child deeply, to master the physical and psychological development profile of the child, to organize play activities that triggers child growth as a whole, which includes the ability to design activities that trigger child mining, assessing the process and results of activities that trigger the development of learners, and make continuous improvements based on the results of assessment of the process and the results of activities that trigger child development, and develop professionalism in a sustainable manner.

\section{Training Part of Out of School Education (PLS)}

In improving the competence there are various ways that can be done by teachers, learn independently through began literature, internet, and comparative studies. But also through joint learning activities through teacher workshops in clusters, attending seminars and education and training.

Training as part of education outside of school becomes one way that can be taken in improving the competence, it is as described

Soelaiman Joesoef and Slamet Santoso in Nurhasanah (2017: 53) provide limits on the PLS whose contents:

"Off-school education is an opportunity where there is regular, targeted communication outside the school and a person obtains knowledge, training or guidance information in 
accordance with age and life needs with the aim of enabling his or her bosses to be efficient and effective participants in the family, work environment and even the community environment and country."

\section{RESEARCH METHODS}

The research method used is a descriptive method, as stated by Arikunto (2010: 126) that "the characteristic descriptive method is satisfying itself on solving the problems that exist in the present at the actual time and the data collected was first compiled, explained and then analyzed ". The approach taken in this research is a qualitative approach.

This data collection is done with several techniques, namely:

1. Interview

2. Observation

3. Documents

The procedure of data analysis in this study refers to what was stated by Nasution (1998: 129-130) ie

1. data reduction

2. display data, and

3. Conclusion and verification.

\section{DISCUSSION}

Based on the results of observations and interviews conducted by researchers to the subject of research, namely 5 respondents who are participants of training courses and training of sustainable professional development (Diklat PKB) in Bandung then the following discussion of research results:

1. The process of planning education and training of Sustainable Development of the profession in improving the pedagogic and professional competence of kindergarten teachers

PKB Training and Training is initiated with coordination and socialization with related parties ie National Instructor or facilitator with the professional organization represented by IGTKI-PGRI chairman and education office of Bandung City with Head of P3TK Head of Duty in charge of increasing the competence of educator and educational staff. Followed by the socialization involves the Chairman of the PKG (Cluster Activity Center) to perform the data collection of participants and the identification of needs seen from the rap on the Management Information System (PKG) PKG PKG members, viewed from the results of UKG in 2016, so that obtained the data participants and mapped into 49 classes with variations of the modules that A, B, C, F, G, H, I, and J modules have to learn, the total number of participants is 1649 teachers. Each teacher can take two modules per year in the available classes. 
The financing of PKB program activities is entirely expensed to APBN (State Revenue and Expenditure Budget) after the process of cooperation submission is received by P4TK TK PLB. The committee is from the element of education service operators and management of IGTKI-PGRI.

2. The implementation process of education and training of Sustainable Development of Keprofesian in improving pedagogic competence and professional kindergarten teacher

PKB Training is conducted within 60 JP (Lesson Hours) with In-On-In face-to-face mode 20:30:10. This pattern shows the number of hours of study, where In-Service Training 1 (In-1) 20 JP, On The Job Learning (On) 30 JP, and In-Service Training 2 (In-2) 10 JP.

The In-On-In Front Facility is held for 13 days. In In-1 for 2 days face-to-face facilitator (National Instructor) with participants in the learning center with PKB training program materials, pedagogic materials and essential content of competency groups 1 and 2 integrated strengthening character education, training questions and technical explanation about self-task in on the job learning attached in the journal.

Then On the participant performs the task according to the self-contained journal for 10 days with an estimated time of $3 \mathrm{JP}$ / day facilitated by the facilitator through the online network (What's Up Group) with essential material resume tasks, working on LK (worksheet), making pedagogic competence and competency professional, and finally made scientific reports.

When In-2 participants meet face-to-face with the facilitator at the learning center, by collecting their assignments, then presentations are represented by several participants, equating perceptions, following the facilitator's exercise, making follow-up and post-test (final) or similar with the UKG (Teacher Competency Test) in 2017 at the TUK (Place Competency Test) at other times.

3. The process of assessment of education and training programs on Sustainable Development of Professionals in improving the professional competence of kindergarten teachers

Assessment of participants is divided into 3 components, namely the value of attitude, skill value and final test. Assessment of attitudes and skills is the authority of the facilitator by looking at the learning and completeness of the tasks of the participants.

As for carrying out the final test there are eligibility requirements that must be possessed by participants to get the username and token, namely: a) daily attendance input on learning full face-face mode of at least $90 \%$ and attendance input at the time of In-1 and In-2 learning respectively fulfilled at least 90\%; b) has completed all tasks and bills to be performed (assignments and charges at the time of On for In-On-In face-toface mode); c) has the value of attitudes and skills acquired during the learning process and has been inputted into the CLA.

For the final test at TUK, the participants are given 45 minutes in each module (the group of competencies) with a total of 30 questions, consisting of 10 pedagogic and 20 professional questions. Each participant worked on two groups of competencies according to his class. Participants who can follow the activities until the final test numbered 1477 participants. 
4. The results of the Training on Sustainable Cultural Development and its impact on improving the performance of kindergarten teachers

Data from sources of P4TK TK and PLB shows the comparison of a value of UKG in 2015 and 2017 in Bandung showed significant improvement from an average value of 45,78 to 73,90 from an element of pedagogic competence and professional competence.

The results of interviews with the respondents also showed that PKB training contributed positively to the participants, by refreshing the previously possessed knowledge, improving the participants' confidence in conducting the teaching and learning activities in the classroom, the learners seemed more energetic with the method of playing while learning given the teacher more varied, the teacher also felt provided in the presentation of progress reports of students to parents, carrying out better counseling guidance to learners, to design preparations for the increase of classes and plans to make PTK (Classroom Action Research). Besides, the participants also expect the improvement of competence especially in the field of ICT (Information and Communication Technology).

\section{E. CONCLUSION}

The Education and Training Program for Continuing Capacity Building is one of the government's efforts to improve teachers' competence in pedagogic and professional competence. This goal will be achieved if teachers and all parties can cooperate in the implementation so as to produce quality services in the school environment. Each teacher has an obligation to develop himself continuously and continuously so that his knowledge can always be refreshed and can build his knowledge through the teacher community, in this case, PKG (Cluster Activity Center) as a workplace for teachers in improving professionalism. Awareness of teachers also needs to be built not only limited to follow the training program, but also apply the results of learning in the field. In addition, it also seeks its own knowledge through various sources, such as the internet, literature materials and makes research of class action or best practice, attend seminars or be a seminar speaker to share his educational experience.

\section{F. REFERENCES}

Mulyasa, H.E. 2013 Competency Test, and Teacher Performance Assessment. Bandung: Rosda.

Mulyono, D. (2017). Menegaskan Karakter Pendidikan Nonformal. Empowerment, 1(1).

Nurhasanah, Santi. 2018. English Teacher Competence Improvement Training Teacher In Bilingual Learning At Bilingual Edit Fithrah Insani West Bandung Regency. Journal of Empowerment Vol.7 (1), p. 50-57

Saud, S.U. (2011) Teacher Professional Development. Bandung: Alfabeta

Team Random Media, (2014). Indonesia Dictionary. Jakarta: Pandom Media Nusantara Yuliani, Sujono (2013). The concept of Dasar for Early Childhood Education. 